\title{
POLITYKA AKTYWIZACJI OSÓB DŁUGOTRWALE BEZROBOTNYCH. EKSPERYMENTY I DOBRE PRAKTYKI - PRÓBA ANALIZY NA PODSTAWIE DOŚWIADCZEŃ HOLANDII, NIEMIEC I POLSKI
}

\section{Abstract \\ Policy of activation of long term unemployed: Experiments and good practices - analysis based on the experience of the Netherlands, Germany and Poland}

The paper reviews the reforms that have been carried out in the Netherlands, Germany and in Poland, in the context of the policy of activating the long-term unemployed. Its purpose was to compare changes made in individual countries and to identify similarities and differences between them. The method of analysis of existing sources and legal acts was used. The text attempts to identify gaps in the system of counteracting long-term unemployment, especially in the context of the rarely undertaken assessment of the measures implemented.

Keywords: unemployment, professional activation, social policy

\section{Streszczenie}

W pracy dokonano przeglądu reform, jakie przeprowadzono w Holandii, Niemczech i Polsce w ramach polityki aktywizującej osoby długotrwale bezrobotne. Celem było porównanie wdrożonych w poszczególnych krajach zmian oraz określenie podobieństw i różnic między nimi. Wykorzystano metodę analizy źródeł zastanych oraz aktów prawnych. Podjęto także próbę wskazania luk systemu przeciwdziałania długotrwałemu bezrobociu, szczególnie w kontekście rzadko podejmowanej oceny wprowadzanych działań.

Słowa kluczowe: bezrobocie, aktywizacja zawodowa, polityka społeczna 


\section{Wstęp}

Reintegracja jednostek wykluczonych z życia społecznego jest jednym z najczęściej wymienianych celów, gdy mowa o polityce społecznej kraju. Za główny środek, który ma służyć jego realizacji, przyjmuje się zwykle aktywizację zawodową osób bezrobotnych. Traktuje się ją jako ważny etap w uzdrawianiu relacji społecznych osób wykluczonych, ale również jako odrębny cel związany z niwelowaniem społecznych skutków bezrobocia, wpisany w zakres zadań krajowego systemu pomocy społecznej. Bezrobocie, zwłaszcza bezrobocie długookresowe, jest problemem wielu krajów znajdujących się na różnym poziomie rozwoju gospodarczego. W ciągu wielu lat w Europie opracowano kilka modeli działań, których celem była aktywizacja osób długotrwale bezrobotnych i przełamanie stereotypu beneficjenta systemów pomocowych jako osoby pasywnej i niezaangażowanej. Celem niniejszej pracy jest analiza reform wprowadzonych w Niemczech i Holandii w omawianym zakresie oraz porównanie niektórych elementów zastosowanych rozwiązań $\mathrm{z}$ wdrażanym $\mathrm{w}$ Polsce systemem przeciwdziałania długookresowemu bezrobociu.

\section{Bezrobocie i bezrobocie długookresowe a wartość kapitału społecznego}

Kamila Słupska-Kwiatkowska, nawiązując do wypowiedzi Ireny Reszke, wskazuje dwa możliwe sposoby oszacowania skali zjawiska bezrobocia: pierwszy to podanie liczby osób zarejestrowanych w odpowiednim urzędzie (w wypadku Polski w urzędzie pracy) - jest to tzw. bezrobocie rejestrowane, a drugi to podsumowanie wyniku przeprowadzonego badania sondażowego, w którym szacuje się liczbę osób niezatrudnionych i poszukujących zatrudnienia oraz zgłaszających gotowość do podjęcia pracy [por. Reszke, 1999; Słupska-Kwiatkowska, 2011]. Drugi opisany przez K. Słupską-Kwiatkowską sposób nawiązuje do definicji stopy bezrobocia przyjętej przez GUS w Badaniu Aktywności Ekonomicznej Ludności (BAEL) [zob. Bezrobotni według BAEL, NSP 2002 i NSP 2011].

Zgodnie z pierwszą z przywołanych definicji osoba bezrobotna ma jedną zasadniczą cechę: jest zarejestrowana $\mathrm{w}$ urzędzie pracy. Takie ujęcie pomija zatem osoby, które mimo braku stałego zatrudnienia nie rejestrują się $\mathrm{w}$ stosownym urzędzie, niejednokrotnie intencjonalnie unikając $w$ ten sposób zobowiązania do udziału w prowadzonych przez dany urząd programach aktywizacyjnych. W raporcie Diagnoza spoteczna za 2015 rok jego autorzy dokonali podziału bezrobotnych zarejestrowanych w urzędach pracy na dwie grupy: bezrobotnych prawdziwych i pozornych. Tych ostatnich z kolei podzielono na niezainteresowanych podjęciem żadnej pracy i osoby pracujące bez umów, zatrudnione na czarno [por. Czapiński, Panek, 2015]. Raport Janusza Czapińskiego i Tomasza Panka wymienia również najczęściej podawane przez respondentów przyczyny nieposzukiwania 
pracy. W grupie kobiet była to zwykle konieczność opieki nad dziećmi. Odpowiedź ta uzyskała najwyższe wskaźniki zarówno w badaniu przeprowadzonym w 2013, jak i w 2015 roku. Wśród mężczyzn dominuje zaś przekonanie o tym, że znalezienie pracy przekracza ich możliwości. W latach 2013-2015 zdecydowanie wzrosła częstotliwość występowania zwłaszcza trzech przyczyn niepodejmowania pracy - były to sytuacja zdrowotna uniemożliwiająca podjęcie zatrudnienia, przekonanie o niemożliwości znalezienia pracy oraz lęk przed utratą świadczeń społecznych [por. Czapiński, Panek, 2015].

W drugiej z przytoczonych przez K. Słupską-Kwiatkowską definicji osobę bezrobotną charakteryzują brak zatrudnienia mimo zgłaszanej chęci do jego podjęcia oraz aktywność w poszukiwaniu pracy. Chodzi tu zatem o grupę ludzi przełamujących stereotyp osoby niezatrudnionej i dotkniętej zjawiskiem wykluczenia z życia społecznego, którego nadrzędną przyczyną jest nieprzystawanie do systemu wartości społecznych opartych na założeniu utylitaryzmu. Wspomniany już raport Diagnoza spoteczna 2015 wskazuje na znaczącą korelację między prawdopodobieństwem utraty pracy oraz pogarszającym się standardem życia. Wśród osób, które jeszcze przed utratą zatrudnienia miały niższe dochody, częściej nadużywały alkoholu, wykazywały wyższy poziom zagrożenia depresją, a także niższy poziom dobrostanu psychicznego i gorszą jakość życia, istnieje większe prawdopodobieństwo utraty pracy. Przy czym autorzy raportu wskazują na częstą znaczącą poprawę jakości życia takich osób po odzyskaniu przez nie posady [por. Czapiński, Panek, 2015].

Osobę bezrobotną definiuje Ustawa $\mathrm{z}$ dnia 20 kwietnia 2004 roku o promocji zatrudnienia i instytucjach rynku pracy. W art. 2 . ust. 1 pkt 2 ustawodawca za osoby bezrobotne uznaje nie tylko osoby niezatrudnione, ale również niezatrudnione i niewykonujące żadnej innej pracy zarobkowej, a zdolne do podjęcia aktywności o takim charakterze w pełnym wymiarze godzin lub częściowo (jeśli osoba ma orzeczony stopień niepełnosprawności lub grupę inwalidzką). W obu przywołanych definicjach istotna jest jednak chęć zmiany swojej sytuacji przez osoby pozostające bez zatrudnienia [por. Ustawa o promocji zatrudnienia i instytucjach rynku pracy, art. 2.1.5].

Ponadto ustawodawca odrębnie definiuje problem bezrobocia długookresowego, określanego czasem jako bezrobocie chroniczne lub długotrwałe. Według zapisów ustawy z 2004 roku osoba długotrwale bezrobotna to ktoś, kto w ciągu ostatnich dwóch lat nie podjął zatrudnienia w okresie dłuższym niż dwanaście miesięcy, z wyjątkiem okresów podejmowania staży lub przygotowania zawodowego osób dorosłych [por. Ustawa o promocji zatrudnienia i instytucjach rynku pracy, art. 2.1.5]. Bezrobocie długookresowe jest znaczącym problemem o charakterze społecznym i dużym wyzwaniem dla polityki społecznej, ponieważ powoduje obniżenie poziomu kapitału społecznego. „Osoby bezrobotne wraz z wydłużaniem się czasu pozostawania bez pracy tracą część swoich umiejętności zawodowych i doświadczenia. W ten sposób znacznie maleją szanse na ich powrót na rynek pracy" [Kucharski, 2015: 178]. Permanentne przebywanie poza rynkiem pracy, a tym samym coraz większe oddalenie od życia społecznego i wyalienowanie $z$ relacji społecznych mogą powodować u osób długotrwale bezrobotnych szereg 
negatywnych konsekwencji o charakterze ekonomicznym, społecznym, moralnym czy psychologicznym. Jeśli chodzi o skutki psychologiczne, często obserwuje się u bezrobotnych obniżenie nastroju, apatię, stany depresyjne, a nawet myśli samobójcze [por. Potasińska, 2015].

Długookresowe bezrobocie zwykle jest sprzężone z syndromem wyuczonej bezradności, który sprowadza się do tego, że jednostka jest przekonana, iż żadna podejmowana przez nią aktywność nie wpłynie na zmianę jej sytuacji życiowej. „Osoby z syndromem wyuczonej bezradności są uzależnione od pomocy z zewnątrz, często przejawiają poczucie krzywdy, niski poziom sensu życia, są wrogo nastawione do ludzi mających lepszą od nich sytuację materialną i wyższy status społeczny. Cechuje ich [!] pesymistyczny styl wyjaśniania doświadczeń życiowych" [Moczydłowska, 2005: 421]. W rezultacie uzależnienie od wsparcia systemowego staje się dla takich osób sposobem na życie.

\section{Częściowa prywatyzacja — reforma holenderska}

Bezrobocie, a szczególnie bezrobocie długookresowe, było jednym z głównych społecznych problemów Holandii na przełomie XX i XXI wieku. Statystyki wskazywały na znacznie większe nasilenie tego problemu niż w krajach ościennych. Grupę szczególnie dotkniętą zjawiskiem długookresowego bezrobocia stanowiły osoby w wieku 50+, a więc pozostające nadal w wieku produkcyjnym, zdolne do pracy, jednak charakteryzujące się znacznie mniejszą skłonnością do podejmowania ryzyka zawodowego, polegającego na przekwalifikowaniu się czy założeniu własnej firmy. Osoby w wieku 50+ stanowiły w Holandii aż ok. 40\% osób długotrwale bezrobotnych [por. Urbaniak, 2008].

Lata dziewięćdziesiąte XX wieku to w Holandii okres dużych zmian. Reformy wprowadzone w tym czasie zaowocowały znacznym spadkiem bezrobocia. Instytucje odpowiedzialne za przeciwdziałanie problemowi braku zatrudnienia i nadzorowanie rynku pracy (Publiczne Służby Zatrudnienia) podlegały wówczas ministerstwu pracy i polityki społecznej. Na początku XXI wieku podjęto decyzję o częściowym sprywatyzowaniu tego systemu. Wyodrębniono wówczas dwie niezależne od siebie grupy, pierwsza obejmowała osoby, które mają prawo do świadczeń finansowych w postaci zasiłku dla bezrobotnego czy osoby niepełnosprawnej, do drugiej zaś zaliczono osoby bez prawa do zasiłku. Za pierwszą grupę odpowiedzialna jest Jednostka Wykonawcza Ubezpieczeń Pracowniczych (UWV), która zajmuje się naliczaniem i wypłatą świadczeń, a za drugą odpowiadają samorządy terytorialne. $W$ ich gestii leży zatem prowadzenie działań aktywizacyjnych. Najistotniejszym elementem tego rozwiązania jest możliwość podjęcia współpracy międzysektorowej, a szczególnie popularne stało się korzystanie $\mathrm{z}$ usług agencji zatrudnienia. Zarządzanie całym procesem aktywizacji pozostawiono jednak w rękach instytucji publicznych [por. Brenninkmeijer, Blonk, 2012].

W Holandii bezrobotnych rejestruje Jednostka Wykonawcza Ubezpieczeń Pracowniczych. Zgłoszenie do UWV jest obowiązkowe. Tam również odbywa 
się wstępne profilowanie klienta, przydziela się go wówczas do jednej z czterech grup: 1 - osób, które nie będą miały trudności ze znalezieniem pracy $i$ istnieje duże prawdopodobieństwo, że szybko znajdą ją same, 2, 3 - osób wymagających reintegracji, 4 - osób znacząco oddalonych od rynku pracy, często mających problemy nie tylko ze znalezieniem zatrudnienia, ale również z funkcjonowaniem w społeczeństwie [por. Finn, 2009]. Jeśli dana osoba kwalifikuje się do otrzymania jednego z oferowanych zasiłków i jednoczesnego podjęcia pracy, zostaje przydzielona do menedżera, który będzie w toku dalszej aktywizacji pracował z nią nad podjęciem pracy. Jeśli zaś klient nie zostanie zakwalifikowany do żadnej formy pomocy oferowanej przez UWV, wówczas oddelegowuje się go do placówki samorządu tery torialnego. Rolę menedżerów odgrywają pracownicy socjalni, którzy na podstawie wywiadów przygotowują plan działania mający na celu znalezienie przez bezrobotnego zatrudnienia w okresie dwunastu miesięcy od rozpoczęcia współpracy [por. KPMG w Polsce, 2013]. Jedną z preferowanych form współpracy jest skierowanie klienta do agencji zatrudnienia. Pracownik socjalny może jednak w porozumieniu z klientem podjąć decyzję o innej formie poszukiwania pracy. Wśród oferowanych przez holenderski system aktywizacji działań popularność szybko zyskały również indywidualne kontrakty reintegracyjne zawierane między stroną a jedną z wybranych przez klienta agencji zatrudnienia. Pula agencji, z których pomocy klient może skorzystać, jest ograniczona do listy wyłonionej w trakcie przetargu organizowanego przez władze lokalne. Kontrakt może być zawarty maksymalnie na dwa lata [por. Finn, 2009].

\section{Ograniczenia i warunki — aktywizacja po niemiecku}

Początek XXI wieku w Niemczech to podobnie jak w wielu innych krajach Europy okres zmagania się ze wzrostem bezrobocia. W 2002 roku jego wskaźnik osiągnął poziom $12 \%$, co wyraźnie wskazywało na nieudolność prowadzonej dotychczas polityki przeciwdziałania temu zjawisku. Rozpoczęto zatem proces reformy systemu, w którym główny nacisk położono na aktywizację osób bezrobotnych. Powołano do działania specjalny organ o nazwie Komisja do spraw Nowoczesnych Świadczeń na Rynku Pracy - jego zadaniem było opracowanie takich narzędzi przeciwdziałania bezrobociu, które niemal zupełnie wyeliminują to zjawisko [por. Jodkowska, 2010].

Reforma systemu wsparcia dla osób bezrobotnych w Niemczech przebiegała pod hasłem „Wspierać i wymagać”, a twarzą kampanii stał się doradca kanclerza Peter Hartz. Podczas badań statystycznych prowadzonych wśród bezrobotnych Niemców odkryto, że tylko co dziesiąta osoba, która straciła pracę, stara się o ponowne podjęcie zatrudnienia [Jodkowska, 2010]. Takie wnioski doprowadziły do zaostrzenia systemu udzielania pomocy finansowej ze strony państwa. Każdy bezrobotny, który chciał się ubiegać o wsparcie systemowe, musiał odtąd spełnić szereg warunków, aby pomoc otrzymać. Stanowiło to bardzo duże ograniczenie, gdyż do tej pory bezrobotni mogli przez trzy lata od utraty zatrudnienia otrzymywać 
specjalne świadczenie, którego wartość była bliska ostatniej pensji, a dodatkowo mogli się starać o objęcie ich pomocą socjalną [Jodkowska, 2010]. Reforma systemu miała zatem zniechęcić osoby bezrobotne do przedłużania okresu pobierania zasiłku oraz przywrócić stan, w którym praca będzie postrzegana jako coś wartościowego, o co powinno się zabiegać, a bezrobocie stanie się dla osób bez wyraźnych przeciwwskazań do podjęcia pracy stanem uciążliwym.

Do osiągnięcia tych celów miały posłużyć nowe narzędzia aktywizujące, przede wszystkim chodziło jednak o przekierowanie strumienia pieniędzy przeznaczonych na pomoc finansową dla bezrobotnych. W pierwszej kolejności podjęto działania edukacyjne na dużą skalę, finansowano kursy doszkalające, zapewniano pieniądze na przekwalifikowanie się, a także inwestowano w poradnictwo zawodowe. Osoba bezrobotna, by korzystać z zasiłków, musiała wykazywać inicjatywę, jeśli chodzi o poprawę swojej sytuacji życiowej, albo udowodnić, że istnieją przyczyny uniemożliwiające jej podjęcie pracy. Osobom, które nie odnajdywały się na otwartym rynku, zaproponowano alternatywne formy zatrudnienia. W ten sposób powstały nowe rodzaje zatrudnienia socjalnego, nazwane Minijob, Midijob i Ein-Euro-Job [Jodkowska, 2010]. Są to formy niskopłatnej pracy dla osób korzystających ze wsparcia systemu pomocy społecznej oraz wsparcia dla osób bezrobotnych. Miały one utrzymać pracownika na rynku pracy, a także wprowadzić pewnego rodzaju zobowiązanie dla osoby bezrobotnej. Udział w programie aktywizującym zapobiegał bierności i ograniczał postawy roszczeniowe. Pojawiła się też możliwość uzyskania dofinansowania na rozpoczęcie własnej działalności, o ile się udowodni, że ma się kwalifikacje, które umożliwią prowadzenie założonej firmy. Postawiono również na indywidualną pracę z klientem, dlatego urzędnicy zatrudnieni w urzędach pracy pełnili odtąd także funkcje konsultantów. Obligowało ich to do udzielania porady osobie szukającej zatrudnienia czy wskazania możliwości szkolenia bądź przekwalifikowania [por. Dragan, 2012].

Niemieckie reformy przyniosły zamierzony rezultat, bowiem w ciągu kilku lat udało się opanować zjawisko bezrobocia, a nawet doprowadzić do jego znaczącego spadku. Niemiecka reforma często postrzegana jest jako bardzo opresyjna, zmuszająca osoby bezrobotne do podjęcia jakiejkolwiek aktywności, ale patrząc obiektywnie, jest ona po prostu oparta na założeniu, że praca jest wartością.

\section{Aktywizacja osób długotrwale bezrobotnych w Polsce}

Podstawę prawną działań aktywizacyjnych w Polsce stanowi Ustawa z dnia 20 kwietnia 2004 roku o promocji zatrudnienia i instytucjach rynku pracy, która w art. 9 ust. 1 pkt 1 głosi, że do zadań samorządu powiatu w zakresie polityki rynku pracy należą opracowanie i realizacja programu promocji zatrudnienia oraz aktywizacji dla lokalnego rynku pracy, który jest elementem składowym powiatowej strategii rozwiązywania problemów społecznych [MRPiPS, 2016]. Do obowiązku prowadzenia aktywnej walki z bezrobociem samorządy zobowiązuje również Ustawa o pomocy społecznej z 2004 roku. Zgodnie z art. 16b tej 
ustawy gmina i powiat opracowują strategię rozwiązywania problemów społecznych, sporządzoną na podstawie przygotowanej wcześniej diagnozy sytuacji społecznej oraz prognoz zmian. Rezultatem prac nad tym dokumentem jest określenie celów strategicznych i kierunków niezbędnych zmian [MRPiPS, 2016].

W 2014 roku uchwalono nowelizację Ustawy o promocji zatrudnienia i instytucjach rynku pracy, która wprowadziła szereg istotnych zmian. Ich głównym celem było nastawienie polityki dotyczącej rynku pracy na zwiększenie zatrudnienia pod kątem kwalifikacji i kompetencji osób bezrobotnych przez podjęcie działań mających na celu przywracanie umiejętności osób bezrobotnych do trwałego włączania się do rynku pracy oraz zwiększenie skuteczności funkcjonowania urzędów pracy. By tego dokonać, zaproponowano wprowadzenie nowych form organizacji pracy i otwarcie się urzędów pracy na kooperację z ośrodkami pomocy społecznej oraz trzecim sektorem, a także prywatnymi agencjami pośrednictwa pracy. Aby zindywidualizować pracę z klientem i dostosować działania do potrzeb konkretnego bezrobotnego i pracodawcy, wprowadzono system profilowania pomocy dla bezrobotnych [por. Ustawa... o zmianie ustawy o promocji zatrudnienia i instytucjach rynku..., 2014].

Profilowanie polega na przydzielaniu osobom bezrobotnym rejestrującym się w urzędzie pracy jednego z trzech profili. Pierwszy przeznaczony jest dla osób aktywnych, które nie wymagają wsparcia. Bezrobocie jest dla nich stanem przejściowym i z dużym prawdopodobieństwem będą w stanie o własnych siłach i wykorzystując własne zasoby, poradzić sobie z zaistniałą sytuacją. Profil drugi charakteryzuje osoby, które mają niezbędne zasoby i potencjał, aby wyjść z trudnej sytuacji, potrzebują jednak wsparcia, by te zasoby wykorzystać. Osoby z profilem trzecim to grupa najbardziej narażona na długotrwałe bezrobocie. Są to tzw. osoby oddalone od rynku pracy, u których potencjał należy dopiero zbudować.

Jak sama nazwa wskazuje, profilowanie w polskim wydaniu - w odróżnieniu od rozwiązań stosowanych w wielu krajach europejskich - nie zmierza do profilowania bezrobotnych w rozumieniu precyzyjnej, wczesnej identyfikacji osób narażonych na pozostawanie bez pracy powyżej 12 miesięcy [...]. Służy zatem przede wszystkim lepszemu adresowaniu dostępnych form aktywizacji do różnych kategorii bezrobotnych [Maksim, Wiśniewski, 2015: 8-9].

Przydzielanie profilu odbywa się przez analizę dwóch czynników: oddalenia od rynku pracy i gotowości do powrotu. Po określeniu profilu sporządza się indywidualny plan działania dla osoby bezrobotnej. W związku z postulowanym w nowelizacji ustawy otwarciem na współpracę międzysektorową opracowano nowe formy wsparcia dla osób bezrobotnych: trójstronne umowy (między państwowymi służbami zatrudnienia, pracodawcą i firmą szkoleniową), specjalne pożyczki na utrzymanie stanowiska pracy lub rozpoczęcie działalności gospodarczej, a także możliwość uzyskania bonu stażowego lub szkoleniowego.

Wprowadzenie nowych form działalności aktywizującej można uznać za pozytywny przejaw zmian w myśleniu o pracy z osobą bezrobotną (na szczególną uwagę zasługuje wątek współpracy międzysektorowej), należy jednak zwrócić 
uwagę, że zastosowane rozwiązania nie są innowacyjne, zostały bowiem zaczerpnięte z podobnych inicjatyw podejmowanych w innych krajach Europy. Zaadaptowanie ich na grunt polski jest traktowane jako eksperyment, korzystający jednak z dobrych praktyk krajów ościennych. Polski pomysł na aktywizację jest znacznie bardziej elastyczny i mniej wymagający niż działania podjęte w Niemczech, a jednocześnie wydaje się, że w mniejszym stopniu wykorzystuje możliwość przekazania części działań poza administrację państwową. Walka z trudnościami społecznymi nadal pozostaje w rękach organów administracji, podmioty prywatne i trzeci sektor odgrywają tu raczej rolę opcjonalnego uzupełnienia niż równorzędnych partnerów. Ponadto osoba bezrobotna oraz długotrwale bezrobotna, niezależnie od przyczyn, dla których znalazła się w takim położeniu, może uzyskać pomoc w ramach systemu pomocy społecznej (np. długofalowe wsparcie finansowe w postaci zasiłków i dofinansowań). Ustawa o pomocy społecznej zobowiązuje bowiem działające na tej podstawie prawnej instytucje pomocowe do wspierania osób dotkniętych problemem bezrobocia. Mimo że system wsparcia socjalnego w Polsce oferuje raczej niewielkie kwoty, często dochodzi do nadużyć (np. wieloletnie pozostawanie klienta w systemie). Instytucje pomocowe starają się ograniczyć ten problem, oferując własne programy proaktywizacyjne dla osób długotrwale bezrobotnych. Tu również dochodzi jednak do kontrowersji, bowiem instytucje pomocy społecznej oraz urzędy pracy często zamiast współpracować dublują swoje działania, przez co niejako ze sobą konkurują. Brak ustawowych instrumentów regulujących kwestie warunkowania świadczeń osobom długotrwale bezrobotnym prezentującym pasywną postawę wobec konieczności poszukiwania pracy sprawia, że rezultaty wprowadzanych programów aktywizujących są niejednokrotnie znacznie mniejsze niż przewidywano.

\section{Podsumowanie}

Jako bezrobotną określa się osobę niezatrudnioną i zarejestrowaną w odpowiedniej instytucji, wykazującą chęć i gotowość do podjęcia pracy. Osoba taka ma prawo do uzyskania wsparcia $\mathrm{z}$ systemu pomocowego obowiązującego $\mathrm{w}$ danym kraju. Przedłużający się okres korzystania z pomocy i brak efektywnych działań aktywizujących może spowodować długookresowe bezrobocie, które w konsekwencji może doprowadzić do obniżenia wartości danej jednostki na rynku pracy. Długotrwale bezrobotni stanowią stały odsetek osób bezrobotnych, są to najczęściej osoby z wykształconym syndromem wyuczonej bezradności, które nie wykazują chęci do podjęcia działań mających na celu zmianę swej sytuacji życiowej. Pogłębianie się tego zjawiska i brak działań aktywizacyjnych kierowanych do tej grupy wpływa negatywnie na jakość kapitału społecznego.

Tworząc strategię dla rozwoju polityki aktywizacji osób bezrobotnych w Polsce, zaadaptowano wiele rozwiązań sprawdzonych w innych krajach europejskich. System, jaki zaproponowano, ma wiele cech wspólnych z wdrożoną w Holandii koncepcją wsparcia osób bezrobotnych, której podstawą jest profilowanie 
klienta w zależności od tzw. oddalenia od rynku pracy, tj. zdolności jednostki do samodzielnego zaktywizowania się zawodowo. Podobnie jak w Holandii, polski system również częściowo korzysta z usług prywatnych podmiotów (np. agencji zatrudnienia). Główna odpowiedzialność za prowadzenie procesu aktywizacji spoczywa jednak nadal na instytucjach publicznych. W przeciwieństwie do reformy holenderskiej polski system nie został do końca ujednolicony, a zadania rozdzielono między instytucje o różnych celach ustawowych (np. zadanie profilowania przydzielono urzędom pracy, które dysponują również usługą doradcy zawodowego i bazą ofert pracy, ale już prowadzeniem Klubów Integracji Społecznej zajmują się instytucje pomocy społecznej). Brak połączenia tych działań i wyraźnej współpracy między poszczególnymi podmiotami powoduje, że przeciwdziałanie bezrobociu z wykorzystaniem wdrożonych elementów jest mniej efektywne. Zasadniczy błąd polega na nakładaniu się zadań i konkurowaniu instytucji ze sobą.

Polski system czerpie również z niemieckiej reformy, szczególnie przez wdrożenie subsydiowanych form zatrudnienia czy programu prac społecznie użytecznych. Działania podejmowane w Polsce są jednak znacznie mniej restrykcyjne wobec beneficjentów. „Wprowadzenie do praktyki urzędów pracy profilowania pomocy, instrumentów zawierających elementy rynkowe i konkurencyjne, a także możliwość zlecania działań aktywizacyjnych osób długotrwale bezrobotnych agencjom zatrudnienia - to kroki w dobrym kierunku" [Maksim, Wiśniewski, 2015: 9]. Rozbudowany system wsparcia socjalnego oferowany przez polskie instytucje pomocy społecznej i rynku pracy wpływa jednak negatywnie na efektywność programów w stosunku do osób długotrwale bezrobotnych. Ustawa o pomocy społecznej z 2004 roku upoważnia pracownika socjalnego do ograniczenia przyznanej pomocy finansowej ze względu na brak współpracy ze strony klienta. Jednym z przykładów takiego zachowania wymienionych przez ustawodawcę jest odmowa udziału w inicjatywach Klubu Integracji Społecznej. Obligatoryjność przyznawania świadczeń i decydująca rola kryterium dochodowego ograniczają jednak możliwość częstego wykorzystywania tych rozwiązań.

\section{Bibliografia}

Bezrobotni według BAEL, NSP 2002 i NSP 2011, https://stat.gov.pl/metainformacje/slownik-pojec/pojecia-stosowane-w-statystyce-publicznej/14,pojecie.html [dostęp: 31.08.2018].

Brenninkmeijer V., Blonk R.W.B. (2012), The Effectiveness of the JOBS Program Among the Long-Term Unemployed: A Randomized Experiment in the Netherlands'. Health Promotion, „Health Promotion International”, 27(2), 220-229https://doi.org/10.1093/heapro/ dar033 [dostęp: 4.05.2017].

Caswell D., Marston G., Larsen J.E. (2010), Unemployed Citizen or 'At Risk' Client? Classification Systems and Employment Services in Denmark and Australia, „Critical Social Policy", 30(3), 384-404.

Czapiński J., Panek T. (red.) (2015), Diagnoza społeczna 2015. Warunki i jakość życia Polaków, http://www.diagnoza.com/pliki/raporty/Diagnoza_raport_2015.pdf [dostęp: 1.06.2018]. 
Dragan A. (2012), Programy walki z bezrobociem na poziomie Unii Europejskiej i w wybranych państwach - Polsce, Finlandii, Irlandii i Niemczech, Kancelaria Senatu, Warszawa.

Finn D. (2009), Differential Pricing in Contracted out Employment Programmes: Review of International Evidence, Department of Work and Pensions, London.

Gallie D., Paugam S., Jacobs S. (2003), Unemployment, Poverty and Social Isolation: Is There a Vicious Circle of Social Exclusion?, „European Societies”, 5(1), 1-32.

Guzikowski M. (2011), Reformujacy Holender, czyli jak wydatki na renty zmniejszyć o połowę, na zasiłki dla bezrobotnych - prawie czterokrotnie i pracować o trzy lata dtużej?, Forum Obywatelskiego Rozwoju, Warszawa.

Jodkowska L. (2010), Rynek pracy w Niemczech w latach 2000-2009. Zmiany form zatrudnienia, „Equilibrium”, 1(4), 119-130.

Kucharski L. (2015), Bezrobocie dtugookresowe w Polsce w latach 2004-2013, „Studia Ekonomiczne", 210, 177-187.

KPMG w Polsce (2013), Nowe podejście do aktywizacji osób bezrobotnych. Doświadczenia polskie i międzynarodowe, http://docplayer.pl/5685106-Nowe-podejscie-do-aktywizacji-osob-bezrobotnych-doswiadczenia-polskie-i-miedzynarodowe-kpmg-pl.html [dostęp: 1.06.2018].

Maksim M., Wiśniewski Z. (2015), Aktywizacja zawodowa dlugotrwale bezrobotnych-nowe tendencje i sposoby działania, „Polityka Społeczna”, 7, 6-10.

Ministerstwo Rodziny, Pracy i Polityki Społecznej [MRPiPS] (2016), Analiza rozwiązań wprowadzonych ustawą z dnia 14 marca 2014 r. o zmianie ustawy o promocji zatrudnienia i instytucjach rynku pracy oraz niektórych innych ustaw (Dz.U. poz. 598), https://www. mpips.gov.pl/download/gfx/mpips/pl/defaultopisy/9826/1/1/EWALUACJA\%20ZBIORCZA-FINAL-6.07.2016.pdf [dostęp: 12.09.2018].

Moczydłowska J. (2005), Wyuczona bezradność - psychologiczna bariera $w$ ograniczaniu nierówności społecznych, „Nierówności Społeczne a Wzrost Gospodarczy”, 6, 419-426.

Potasińska A. (2015), Konsekwencje bezrobocia w wymiarze godności człowieka, „Roczniki Nauk Społecznych", 43(4), 73-84.

Reszke I. (1999), Wobec bezrobocia. Opinie, stereotypy, https://repozytorium.amu.edu. pl/bitstream/10593/4173/1/Kamila_S\%C5\%82upska-Kwiatkowska\%2C_Bezrobocie Pracamo\%C5\%BCliwo\%C5\%9B\%C4\%87_zaspokajania_potrzeb-perspektywy.pdf [dostęp: 12.06.2017].

Słupska-Kwiatkowska K. (2011), Bezrobocie. Praca-możliwość zaspokojenia potrzeb-perspektywy, czyli o tym, co robić by ta triada mogła się urzeczywistnić [w:] E. Włodarczyk, I. Cytlak (red.), Człowiek wobec krytycznych sytuacji życiowych. Z teorii i praktyki pracy socjalnej (s. 53-71), Wydawnictwo Naukowe UAM, Poznań.

Ustawa z dnia 12 marca 2004 r. o pomocy społecznej, Dz.U. z 2004 r. Nr 64 poz 593.

Ustawa z dnia 20 kwietnia 2004 r. o promocji zatrudnienia i instytucjach rynku pracy, Dz.U. z 2004 r. Nr 99 poz. 1001.

Ustawa z dnia 14 marca 2014 r. o zmianie ustawy o promocji zatrudnienia i instytucjach rynku pracy oraz niektórych innych ustaw, Dz.U. poz. 598.

Urbaniak B. (2008), Wyzwania wobec edukacji starszych pracowników w Polsce [w:] J.T. Kowaleski, T. Szukalski (red.), Pomyślne starzenie się w perspektywie nauk o pracy i polityce społecznej, Zakład Demografii i Gerontologii Społecznej Uniwersytetu Łódzkiego, Łódź. 